Article

\title{
What Do Students Know about Rivers and Their Management? Analysis by Educational Stages and Territories
}

\author{
Rubén Ladrera ${ }^{1} \mathbb{D}$, Pablo Rodríguez-Lozano ${ }^{2, *} \mathbb{C}$, Iraima Verkaik ${ }^{3}$, Narcís Prat ${ }^{3} \mathbb{C}$ and \\ José Ramón Díez ${ }^{4}$ (i) \\ 1 Area of Didactics of Experimental Sciences, Department of Agriculture and Food, University of La Rioja, \\ 26006 Logroño, Spain; ruben.ladrera@unirioja.es \\ 2 Department of Geography, University of the Balearic Islands, 07122 Palma, Spain \\ 3 Freshwater Ecology, Hydrology and Management Research Group, University of Barcelona, \\ 08007 Barcelona, Spain; iverkaik@ub.edu (I.V.); nprat@ub.edu (N.P.) \\ 4 Department of Mathematics and Experimental Sciences Education, University of the Basque Country, \\ 48940 Leioa, Spain; joseramon.diez@ehu.eus \\ * Correspondence: pablo.rodriguez@uib.es
}

Received: 10 September 2020; Accepted: 19 October 2020; Published: 21 October 2020

\begin{abstract}
The overall purpose of this study was to assess the knowledge that students have about the ecosystem concept of rivers and their sustainable management. A survey of nine questions gathered responses from 3447 students at three different Spanish education levels (Primary, Secondary, and bachelor's degree in Primary Education) and six different geographic territories in the Iberian Peninsula. Respondents showed a limited understanding of rivers, much simpler than the ecosystem concept, which was related to proposals of unsustainable management of these ecosystems. Although the results were analogous among territories, undergraduate students had a more complex concept of rivers as well as more sustainable ideas regarding their management compared with Primary and Secondary Education students. This study demonstrates the lack of knowledge transfer between science and students regarding river ecosystems. Current educational programs should be adapted to address, even at early stages of education, the sustainability challenges around river ecosystems.
\end{abstract}

Keywords: river; education for sustainability; environmental education; educational stages; ecosystem concept; sustainable river management

\section{Introduction}

Rivers are complex ecosystems from both structural and functional perspectives [1]. Since the 1970s, river scientists have adopted an integrative catchment view of streams, recognizing that rivers are not separated phenomena, but parts of the valleys they drain [2]. Many river science theories have emerged and been tested and developed since then, such as the river continuum concept, the flood pulse hypothesis, and the nutrient spiraling concept [3-5]. The growing body of literature on river science has constructed the ecosystem concept of rivers from a holistic perspective, which supports the design of sustainable management measures. However, rivers have been treated historically as mere pipes by river management policies, which used to have a hydraulic perspective instead of a hydroecological framework [6]. Past unsustainable management practices led to the degradation of rivers $[7,8]$. In fact, rivers are still frequently perceived as water channels that flow into the sea, despite current scientific knowledge [9]. Similarly, the value of the diversity of existing river ecosystems is rarely recognized [10], as well as the biotic and abiotic elements needed for their conservation [11,12]. 
Compulsory education can play a key role in reverting river degradation because it should be one of the ways to transfer scientific knowledge to all citizens. Indeed, compulsory education should be a main factor in the transition towards a sustainable society, and students should be prepared for their present and future role in that transition $[13,14]$. Regarding rivers, it is necessary to work in two interrelated lines: (i) the construction of a conceptual approach to rivers from an ecosystem perspective, which is a greater challenge than merely building up knowledge, and (ii) the acquisition of the necessary skills for decision-making towards water use and sustainable river management. These two work lines are aligned with several Sustainable Development Goals (SDGs), such as promoting sustainable management of water (SDG 6) and all SDGs focused on the protection of our planet (SDGs 11-15), but mainly with the SDG 4.7 target, which aims to "ensure that all learners acquire the knowledge and skills needed to promote sustainable development, including, among others, through education for sustainable development and sustainable lifestyles" [15]. Therefore, scientific literacy regarding the ecosystem concept of rivers and their sustainable management can help river conservation because it may facilitate citizens' support of sustainable policies related to river management.

The ecosystem concept of rivers requires going beyond simplified hydraulic perspectives. Elements such as the diversity of living beings, the role of organic matter, riverside vegetation, abiotic components, the importance of habitat diversity, and the complex interdependence between all of them should be recognized. Likewise, the river as an ecosystem must be conceived as part of the whole watershed it drains, taking into account what occurs in the linked terrestrial systems. The conservation of a river section not only depends on local factors, but on all impacts and pressures at the basin level. Students with an ecosystem concept of rivers should be able to recognize sustainable river management measures. In this vein, the construction of the ecosystem concept of rivers is a type of environmental science literacy [16], i.e., a significant familiarization with the concepts and processes related to rivers that make it possible to make responsible decisions about their management [17-19].

We consider it necessary to delve into the construction of mental models about river ecosystems that involve ecological and social dimensions because they are essential to developing critical attitudes towards everyday issues related to their management [20]. In fact, previous studies have revealed important limitations among students in understanding key water-related issues [21-24]. These limitations have been related to different aspects, such as the teaching methods [25], teachers' training [26], and the lack of students' direct contact with the territory during the learning process [20]. In this vein, some studies have tried to assess students' knowledge and perception related to rivers through questionnaires with closed questions [9], open descriptive questions, and hands-on experiences [20,27]. These studies suggest that students' concept of rivers is simpler than the ecosystem concept. It is worth noting that these studies are scarce and limited to one educational level and small territories $[9,20]$. Consequently, assessing students' knowledge about the ecosystem concept of rivers and their management across educational levels and territories is necessary.

Notably, current Spanish legislation (Spanish Royal Legislative Decrees126/2014 and 1105/2014; [28,29]) includes elements about sustainable development and the environment as curricular contents of these educational stages. According to official learning standards, Primary Education students should be able to identify main components and characteristics of ecosystems, describe the water cycle, and explain the sustainable use of natural resources, being able to propose measures to improve environmental conditions [29]. Secondary Education students should have the ability to analyze and interpret data about water, droughts, and hydrological regimens, and to value sustainable water management and recognize specific management measures [28]. Indeed, rivers and their sustainable management are common topics throughout all educational levels, including both Primary and Secondary Education [30,31]. Therefore, students of Primary and Secondary Education should be able to understand the ecosystem concept of rivers and their sustainable management.

The study's goal was to assess students' knowledge regarding (i) the ecosystem concept of rivers and (ii) sustainable river management. To achieve this objective, we carried out a survey of thousands of students. We aimed to test for differences among educational levels; thus, we differentiated among 
three levels: Primary Education students, Secondary Education students, and university students of a bachelor's degree in Primary Education. Moreover, we explored if students' knowledge varied among territories that differed in their climatic conditions, river typologies, and conflicts around water management

\section{Materials and Methods}

\subsection{Survey Design and Distribution}

An online survey was carried out to measure students' knowledge about the ecosystem concept of rivers and their sustainable management. The survey was distributed among three different educational levels: the sixth year of Primary Education (last course of Primary Education, 10-11 years old), the third year of Secondary Education (last year in which a course in Biology and Geology is compulsory, 14-15 years old) and the third year of the Bachelor of Primary Education degree (future Primary Education teachers). We differentiated among six territories within mainland Spain that differed in their climatic conditions, river typologies, and conflicts around water management (Figure 1). These territories ( $\mathrm{T}$ ) were identified according to their latitude (from higher to lower latitude) and included the following provinces: T.1, Álava, Bizkaia, and Gipuzkoa (Oceanic climate; a large amount of precipitation and surface run-off); T.2, Navarra and La Rioja (Mediterranean climate with transitions to an Oceanic climate; mainly located in the upper part of the Ebro basin); T.3, Girona, Barcelona, and Tarragona (Mediterranean climate influenced by the coast; historical water conflicts such as the one around the Ebro Delta); T.4, Guadalajara, Madrid, and Toledo (Mediterranean climate with transitions to a cold, semi-arid climate; located in the upper part of the Tajo basin where the Spanish largest water transfer is extracted to T.5); T.5, Valencia, Alicante, Murcia, and Almería (hot, semi-arid climate with transitions to a Mediterranean climate; very low precipitations, and intensive agriculture activity with large water consumption transferred from T4); T.6, Córdoba, Sevilla, Cádiz, and Huelva (Mediterranean climate; located in the lower course of the Guadiana and Guadalquivir rivers).

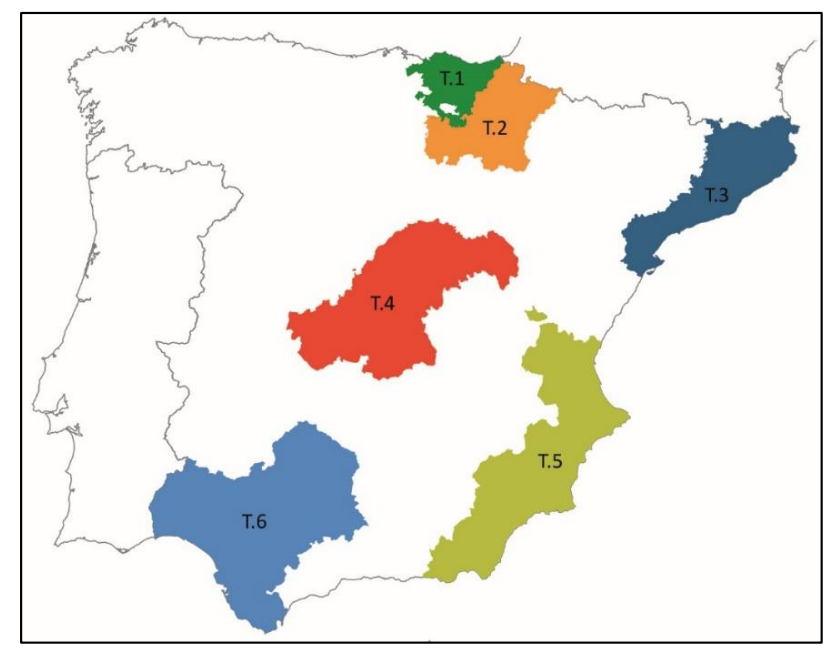

Figure 1. Territories (T) where the surveys were completed. T.1: Álava, Bizkaia, and Gipuzkoa. T.2: Navarra, and La Rioja. T.3: Girona, Barcelona, and Tarragona. T.4: Guadalajara, Madrid, and Toledo. T.5: Valencia, Alicante, Murcia, and Almería. T.6: Córdoba, Sevilla, Cádiz, and Huelva.

The survey was based on a previous survey that focused on students from Secondary Education [9]. The improved survey was validated by experts in stream ecology and pedagogy of experimental sciences. As part of the validation process, the survey was distributed to 50 students of Primary Education and 50 students of Secondary Education to detect any comprehension problem, since the same survey had to be well understood by the students of the three educational levels. The final survey (Figure 2) consisted of nine closed questions with five response options each, except Question 5 
that had one more option. Five questions were single response questions (Questions 3-7), while the others were multiple response questions for which respondents could mark more than one answer (Questions 1, 2, 8, and 9). As stated before, the survey focused on two topics: the ecosystem concept of rivers (Questions 1-5) and sustainable river management (Questions 6-9). Questions regarding the ecosystem concept of rivers included aspects related to rivers' biotic and abiotic components and to the assessment of river conservation status, whilst river management covered topics from flooding risk management to management policies to avoid scarcity problems.

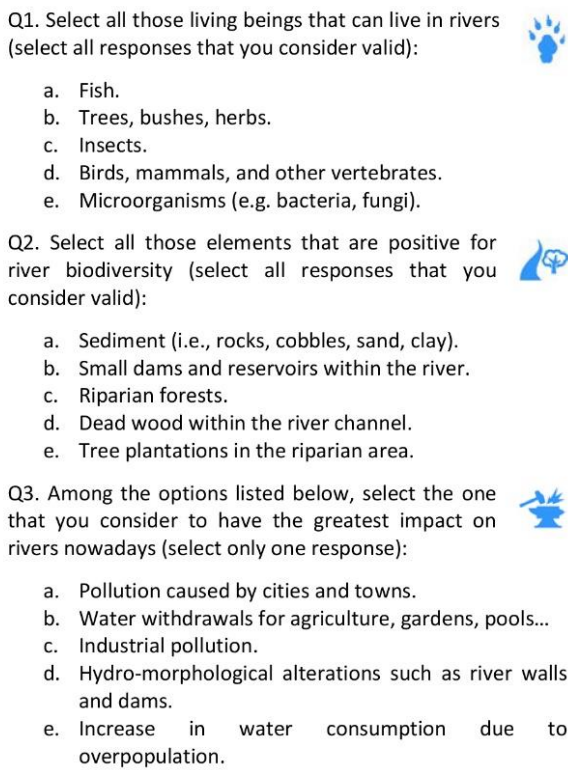

d. Hydro-morphological alterations such as river walls and dams.

e. Increase in water consumption due to overpopulation.

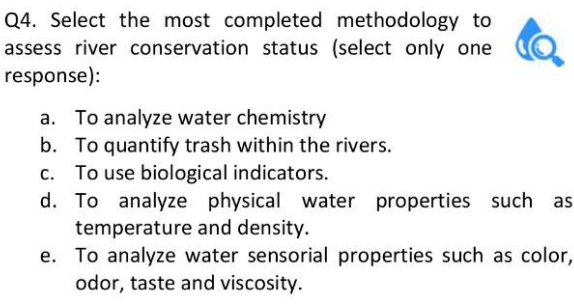

e. To analyze water sensorial properties such as color, odor, taste and viscosity.

Q5. Which of the river transects in the images do you think is the best conserved? (select only one response)
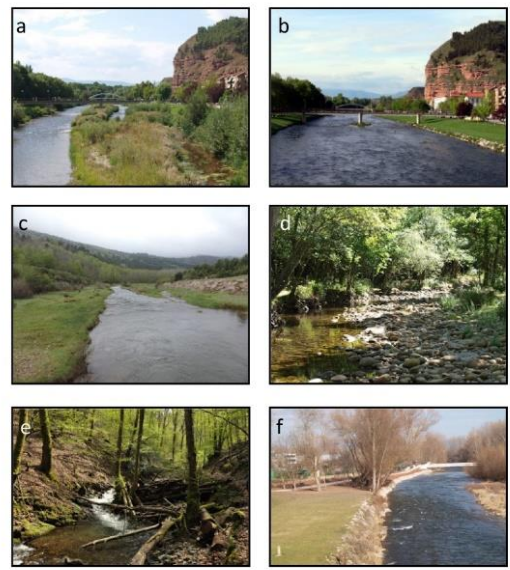

Q6. Which do you consider the best management measure to avoid water scarcity problems during droughts? (select only one response)

a. To build more reservoirs to avoid losing freshwater into the sea.

b. To avoid building facilities such as swimming pools and golf courses in areas with water shortages.

c. To transfer water from regions without water shortages to regions where droughts are common.

d. To reduce water consumption through water saving measures.

e. To build water storage tanks to accumulate rainwater.

Q7. What do you think would be the best management measure to reduce flooding risk? (select only one response):

a. To build more reservoirs and to enlarge existing ones to control water volume in rivers.

b. To build walls in river shores to avoid water to overflow.

c. To avoid human settlements and industrial and farming activities near rivers, in flood plains.

d. To dredge (removing rocks and cobbles to make the river deeper) and clean rivers (removing wood, branches, and vegetation that grows within the river channel).

e. To renaturalize rivers, letting rivers flow through their historical course with meanders and wide riparian forests.
Q8. Among the elements listed below, which ones would you remove to clean a river in your region (select all responses that you consider valid)

a. Bushes and small herbs in the river shores.

b. Trees in the river shores.

c. Branches and logs.

d. Vegetation growing within the river channel.

e. I would not eliminate any of the listed elements.

Q9. Select those actions that you would carry out to improve the current state of Spanish rivers (select all responses that you consider valid):

a. I would do a management plan to transfer water from regions with higher water availability to those suffering water shortages.

b. I would channelize rivers in most cities and towns to avoid growing vegetation within river channels.

c. I would avoid building new reservoirs, thus rivers would have enough flow to transport sediments to their river mouths.

d. I would do a management plan to increase the price of water extracted from rivers and aquifers, thus people would consume only the water they truly need.

e. I would try to reduce the fertilizers and pesticides used in agricultural practices.

Figure 2. English translation of the original Spanish-language questionnaire for the present study. Questions (Q) Q1-Q5 refer to river ecosystem concept and Q6-Q9 refer to river management. 
Between October 2017 and March 2018, the survey was distributed online to all educational centers of Primary and Secondary Education located in the territories included in this study. For this purpose, electronic addresses that were publicly available on the webpages of the public administration were used. We asked for volunteer participation of the professors teaching Natural Sciences to students enrolled in the sixth year of Primary Education, and those teaching Biology and Geology to students in the third year of Secondary Education. All educational centers received detailed information regarding the study's goals and the methods they should follow to carry out the survey in their classrooms. Likewise, we contacted university professors of the Bachelor of Primary Education degree working in the public universities located within the territories included in this study. A total of 3447 responses were collected, which represents about $0.5 \%$ of the focus population. The response distribution among territories was: $\mathrm{T} 1=644, \mathrm{~T} 2=715, \mathrm{~T} 3=505, \mathrm{~T} 4=384, \mathrm{~T} 5=644$, and $\mathrm{T} 6=555$. Of the 3447 responses, 1232 (36\%) were Primary Education students, 1883 (54\%) were Secondary Education students, and 332 $(10 \%)$ were university students.

\subsection{Assessment of Survey Responses}

Survey responses were not considered right or wrong, but they were analyzed to assess if students had an ecosystem concept of rivers and their preference for sustainable or non-sustainable management measures. Subsequently, results were interpreted based on the large body of scientific literature about this topic and current environmental legislation.

Based on current scientific knowledge, it was considered that the ecosystem concept of rivers is associated with the following responses: (i) the identification of the five types of living beings proposed in Question 1; (ii) the selection of sediment, riparian forest, and dead wood as positive elements for biodiversity, since any of them favors the appearance of new habitats (Question 2, Survey Responses a, c, and d); (iii) biological indicators as the best methodology to assess river conservation status because they integrate more information about the state of the ecosystem (Question 4, Survey Response d); and (iv) pictures of river transects without anthropic elements that clearly alter river ecosystems (Images $d$ and e of Question 5). On the other hand, the goal of Question 3 was to know how students perceive different anthropic impacts, which gave us information about their general perception of the components of river ecosystems.

Regarding river management, it is considered that sustainable river management should favor (i) the reduction of water consumption, according to the current climate scenario (Question 6, Survey Responses b and d); (ii) flood risk management models that promote correct spatial planning and the renaturalization of rivers (Question 7, Survey Responses c and e); (iii) river management projects that try to maintain any of the elements proposed in Question 8; (iv) general management models that favor the natural dynamics of rivers, and reduce water consumption and pollution (Question 9, Survey Responses c, d, and e).

\subsection{Data Analysis}

The percentage of respondents who marked each of the possible answers was calculated for each question, also differentiating between the three educational levels and territories. Based on these data, two grouped response arrays were constructed: one with the response frequencies for questions regarding the ecosystem concept of rivers (Questions 1-5), and a second one for questions focused on river management (Questions 6-9). To examine the similarities in the survey responses among educational levels and territories, a Principal Coordinates Analysis (PCoA; [32]) was calculated for each similarity matrix (Euclidean distance) after the log-transformation $(\log (x+1))$ and standardization of the data. Then, an ANOSIM (Analysis of Similarities; [33]) was carried out with the similarity matrix to test for differences among educational levels and territories. Finally, Spearman correlations between the first axis of the PCoA and the questions' answers (71 items) were calculated in order to know which answers influenced the groups' distribution within the two-dimensional representation of the PCoA. All statistical analyses were performed on PRIMER v6 + PERMANOVA software. 


\section{Results}

\subsection{Ecosystem Concept of Rivers}

Almost every student identified fishes as organisms that inhabit rivers (Figure 3, Q1), but the rest of the organisms (plants, insects, vertebrates, and microorganisms) were recognized as inhabitants of these ecosystems to a lesser extent. The percentage of respondents who recognized plants, insects, and vertebrates as inhabitants of rivers increased with educational level (Figure 3, Q1), from about 40\% of Primary Education students to $60-80 \%$ of university students. With respect to the elements that contribute to river biodiversity, we observed a similar pattern for sediment, riparian forest, and tree plantations being chosen by around 50\% of students of Primary Education and progressively increasing in higher educational levels (Figure 3, Q2). It is worth noting that less than $20 \%$ of respondents from all educational levels identified death wood pieces as positive elements for river biodiversity, while human-introduced elements (tree plantations, small dams, and reservoirs) were marked by a higher number of respondents (Figure 3, Q2).
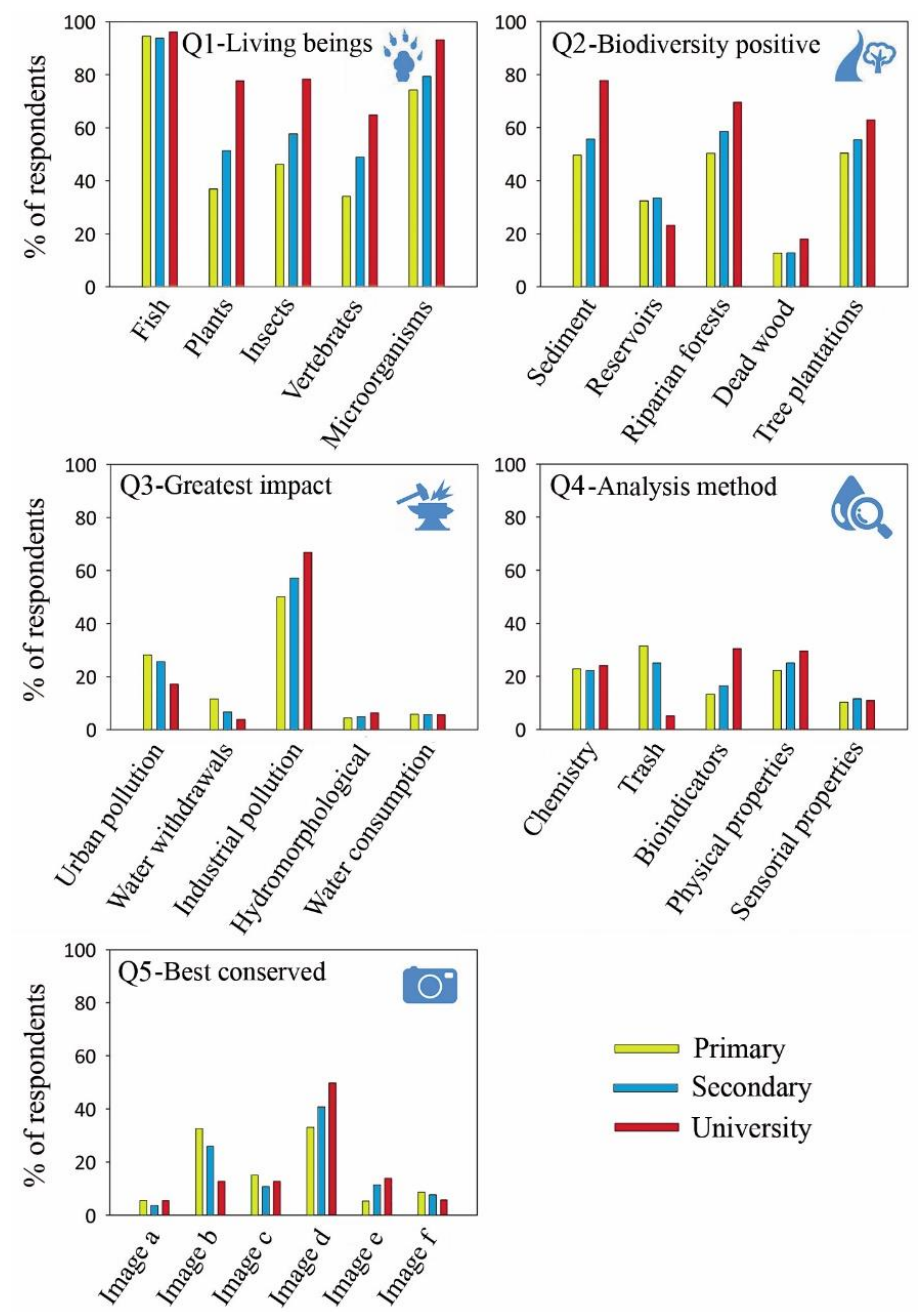

Figure 3. Percentage of respondents (\%), grouped by educational stage, that marked each response option of questions related to the river ecosystem concept. Questions (Q) focused on living beings inhabiting rivers (Q1), elements related to river biodiversity (Q2), impacts on rivers (Q3), methodologies to assess river conservation status (Q4), and perception of the conservation status of rivers depicted in images (Q5). See questions and response options in Figure 2. 
Industrial and urban pollution were chosen as the main problems for rivers by most students from all educational levels (about $80 \%$ ), while water withdrawals and hydromorphological alterations were chosen by a minority of respondents (Figure 3, Q3). In contrast, there was a large dissent regarding the best method to assess the conservation status of rivers (Figure 3, Q4). "Trash quantity" was the most selected method by Primary Education students, while "biological indicators" was the answer most chosen by university students. Regarding the image-based question (Figure 3, Q5), Picture d, depicting a well-conserved headwater stream, was identified as the best-conserved river by most students, and its selection increased with educational level. The image showing an urban river after a "cleaning" action (Picture b) was marked by a similar percentage of Primary Education students (almost 33\%) as Picture d, and by a higher percentage than Picture e, the other diverse and well-conserved stream included in the questionnaire. The selection of Picture b decreased when increasing the educational level (Figure 3, Q5), while the percentage of students who marked Picture $d$ increased with educational level.

The PCoA plot (Figure 4) based on the survey responses related to the ecosystem concept of rivers (Questions 1-5) provided an interpretable two-dimensional ordination plot of the survey responses grouped by educational level and territory. The PCoA plot shows a clear separation of the educational levels along its first axis, which explains the $45.2 \%$ of the total variance. In this vein, ANOSIM demonstrated that the differences between educational levels were statistically significant $(R>0.4$, $p$-value $<0.01$ for all pair-wise comparisons). The highest difference was found between Primary Education students and university students $(\mathrm{R}=0.785, p$-value $=0.002)$. In contrast, no significant differences among territories were found ( $p$-value $>0.2$ for all pair-wise comparisons). Twelve of the 26 answers were strongly correlated with the first axis of the PCoA (Spearman correlation coefficient $>0.7$ Table 1), thus, they were identified as the answers that explained the groups' distribution within the PCoA along the first axis. Answers that were negatively correlated with the first axis of the PCoA were associated with higher educational levels, while answers positively correlated were associated with lower educational levels (Table 1). It is worth noting that students of higher educational levels were able to correctly identify more organisms that inhabit rivers and more elements that improve river biodiversity (i.e., riparian forest, sediment). Similarly, the selection of bioindicators as the best method to assess river conservation status and the identification of the image depicting the best-conserved river increased with educational level (Table 1).

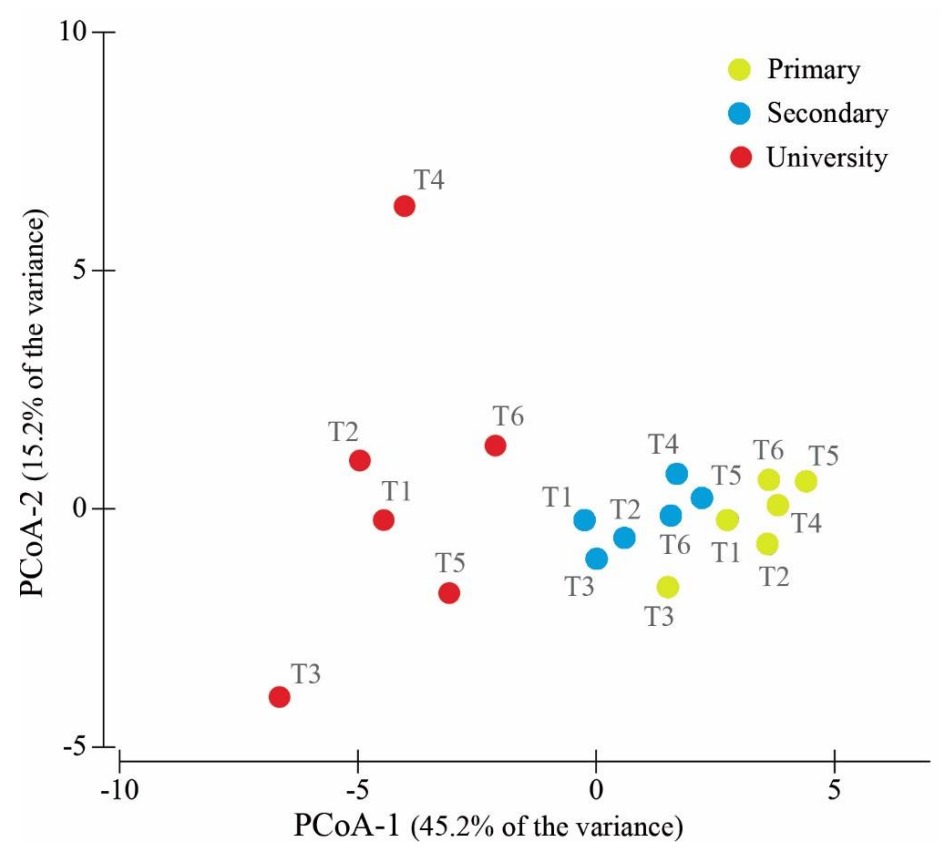

Figure 4. Principal Coordinates Analysis (PCoA) results showing the 18 groups of students grouped by educational stage (green, orange, and red) and territory (T1-T6), based on answers to the questions referring to the river ecosystem concept. 
Table 1. Responses related to the river ecosystem concept that were correlated with the first axis of the Principal Coordinates Analysis (PCoA) with a higher absolute value of Spearman correlation index of 0.7.

\begin{tabular}{cl}
\hline R Spearman & \multicolumn{1}{c}{ Response } \\
\hline-0.930 & 1.d. Living beings that inhabit rivers: Birds, mammals, and other vertebrates. \\
-0.917 & 1.b. Living beings that inhabit rivers: Trees, brushes, herbs. \\
-0.911 & 2.c. Elements that are positive for river biodiversity: Riparian forests. \\
-0.901 & 2.a. Elements that are positive for river biodiversity: Sediment (i.e., rocks, cobbles, sand, clay). \\
-0.866 & 4.c. Best methodology to assess river conservation status: Bioindicators. \\
-0.864 & 1.e. Living beings that inhabit rivers: Microorganisms (e.g., bacteria, fungi). \\
-0.837 & 5.d. Image of the best-conserved river transect: Image d, well-conserved headwater stream. \\
-0.829 & 1.c. Living beings that inhabit rivers: Insects. \\
-0.707 & 2.e. Elements that are positive for river biodiversity: Tree plantations in the riparian area. \\
\hline 0.750 & 3.a. Greatest impact on rivers nowadays: Pollution caused by cities and towns. \\
0.865 & 4.b. Best methodology to assess river conservation status: To quantify trash. \\
0.934 & 5.b. Image of the best-conserved river transect: Image b, urban stream after a "cleaning" action. \\
\hline
\end{tabular}

\subsection{River Management}

Reducing water consumption was the preferred measure to prevent water scarcity problems by all educational levels, being more commonly selected by university students (Figure 5, Q6). Although the other answer options were chosen by a lower number of respondents, the construction of reservoirs and water deposits were less commonly selected by university students than by Primary and Secondary Education students. Regarding flooding risk mitigation, naturalizing rivers was the management policy most selected by university students $(>40 \%)$ while only $20 \%$ for Primary and Secondary Education students (Figure 5, Q7). Moreover, non-sustainable measures (i.e., river channelization, construction of walls in river shores, and dredging and clearing vegetation growing within river channels) were less elected by university students than by students from lower educational levels.

About half of the respondents would eliminate branches and logs from the river channel (Figure 5, Q8), but the selection of this response option decreased when increasing the educational level. Despite all river elements proposed to be eliminated were important for river biodiversity and functioning, only a minority of respondents (about 20\%) chose the option of "do not eliminate any of them". There was not a strong pattern with respect to general measures to improve Spanish rivers (Figure 5, Q9). However, "to reduce agrochemicals use" was the preferred policy for university students, who marked in less proportion the policies to "channelize rivers" and "increase water prices" when compared with students from lower educational levels.

Based on the questions about river management (Questions 6-9), the PCoA plot showed a clear separation between university students and Primary and Secondary Education ones (Figure 6). However, no clear separation between Primary and Secondary Education was observed. ANOSIM results confirmed this pattern: responses of university students differed from those of Primary Education $(R=0.51, p$-value $=0.002)$ and Secondary Education students $(R=0.45, p$-value $=0.002)$, while no significant differences were found between Primary and Secondary Education levels $(R=0.026$, $p$-value $=0.34$ ). Significant differences among territories were not observed ( $p$-value $>0.1$ for all pair-wise comparisons). Spearman correlations revealed that six of the 20 answer options had a strong correlation with the first axis of the PCoA (Spearman correlation coefficient $>0.7$, Table 2). Answers that were negatively correlated with the first axis of the PCoA were associated with the responses of university students, while answers positively correlated were associated with those of Primary and Secondary Education. Compared to Primary and Secondary Education, university students identified more sustainable management practices to reduce flooding risks, such as river naturalization, and tended to avoid non-sustainable practices, such as river channelization or intrusive river cleaning. 


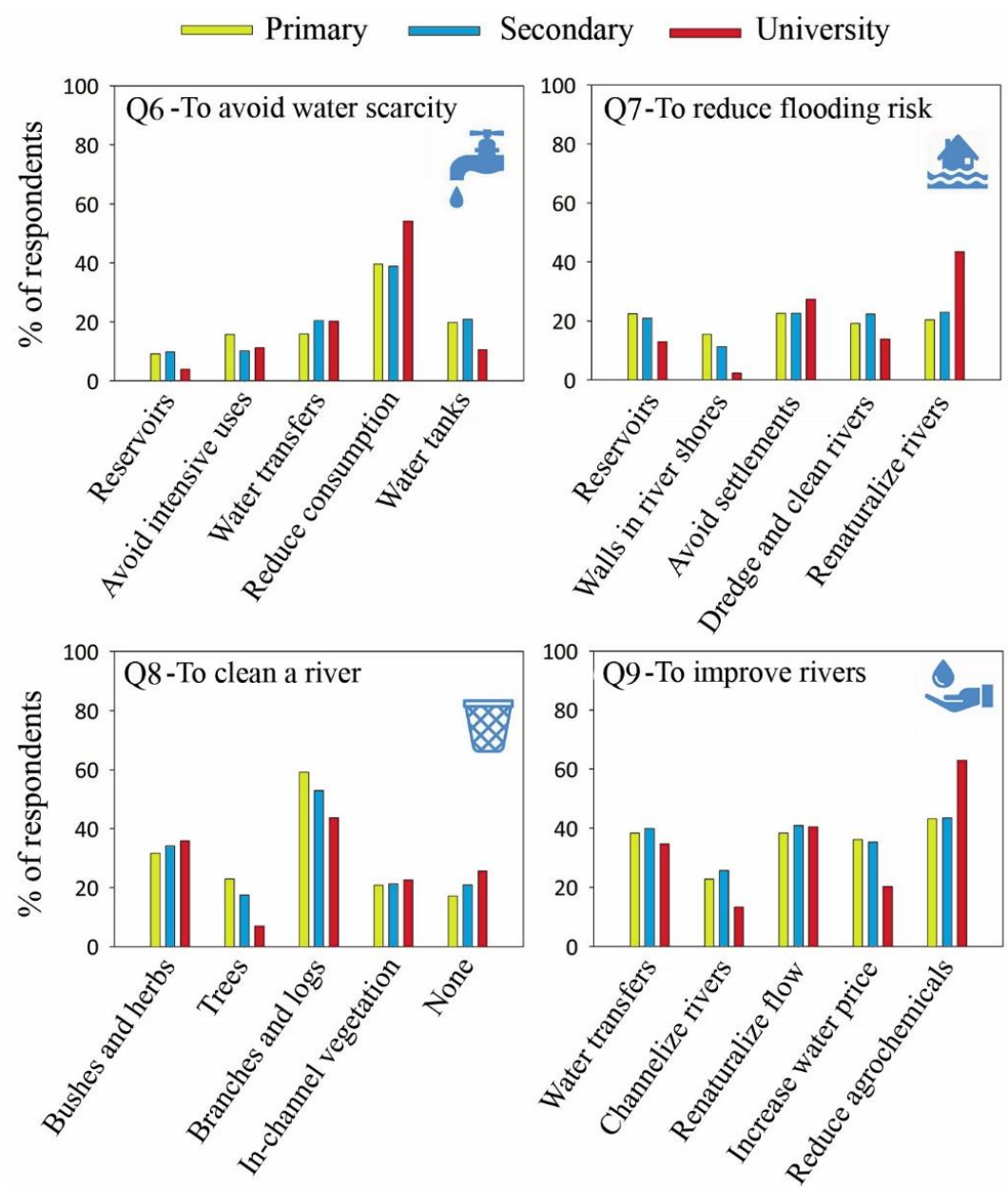

Figure 5. Percentage of respondents (\%), grouped by educational stage, that marked each response option of questions related to river management. Questions (Q) focused on drought management (Q6), flooding risk management (Q7), cleaning actions (Q8), and general water management strategies (Q9). See questions and response options in Figure 2.

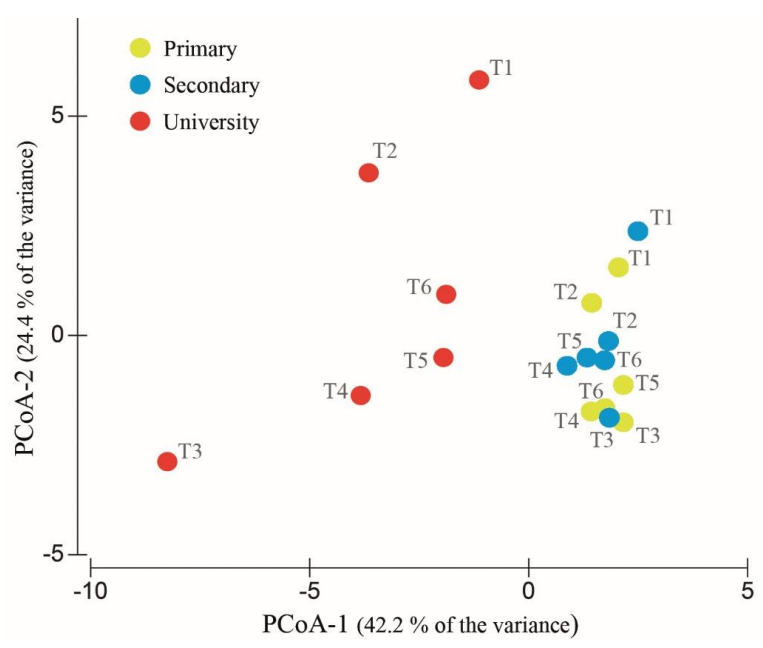

Figure 6. Principal Coordinates Analysis (PCoA) results showing the 18 groups of students, grouped by educational stage (green, orange, and red) and territory (T1-T6), based on answers to the questions referring to river management. 
Table 2. Responses related to river management that were correlated with the first axis of the Principal Coordinates Analysis (PCoA) with a higher absolute value of a Spearman correlation index of 0.7.

\begin{tabular}{cl}
\hline R Spearman & \multicolumn{1}{c}{ Response } \\
\hline-0.835 & 9.e. General management measure: Reducing fertilizers and pesticides in agriculture. \\
-0.760 & 7.c. Best measure to reduce flooding risk: Renaturalize rivers. \\
\hline 0.706 & 7.b. Best measure to reduce flooding risk: Walls in river shores. \\
0.730 & 9.b. General management measure: Channelizing rivers in cities and towns. \\
0.782 & 9.d. General management measure: Increasing water price to reduce consumption. \\
0.834 & 7.d. Best measure to reduce flooding risk: Dredging and cleaning. \\
\hline
\end{tabular}

\section{Discussion}

\subsection{Ecosystem Concept of Rivers}

The survey responses revealed that the students of all three educational levels did not know key aspects related to rivers' basic ecology, such as the different groups of living beings that inhabit rivers, the importance of riverside vegetation, the role of organic matter in its different forms, and the relevance of abiotic components (e.g., sediment diversity). These aspects are needed to understand rivers' complexity and to approach them as ecosystems, instead of understanding them as simple water channels where water flows to the sea. Notably, wood presence within the river channel was considered positive for river biodiversity by less than $20 \%$ of students. Previous studies have reported that students [12] and the general public [11] have negative perceptions towards wood in riverscapes, despite the several ecological benefits that dead wood provides to these ecosystems [34]. In general, riverscapes containing dead wood are perceived as less aesthetically attractive and more dangerous compared with riverscapes lacking these elements [11,12]. In this vein, it has been argued that the historical management practice of eliminating dead wood from river channels could have prevented people from perceiving dead wood as a natural element of riverscapes. Consequently, educators, managers, and policymakers should play a key role in reverting this misperception.

It also worth noting that hydrological and hydromorphological impacts were rarely perceived as current major threats for rivers by students of the three educational levels ( $<12 \%$ of respondents of any educational level selected these responses). Our results suggest that students placed most of their attention on water quality issues. Most students marked water pollution from both urban and industrial sources as major threats for rivers, and considered chemical and physical water analysis as good methods to assess river conservation status. These students' perceptions align with the strategic lines marked by the European Union during past decades regarding river management, which have focused on assessing and solving water quality issues throughout Europe [6]. However, it contrasts with the current scientific knowledge about rivers, their current legal regulation, and their conservation status in the European Union and other world areas (e.g., United States of America, Canada, Australia). Most European rivers have improved their physicochemical status and, consequently, current European legislation [35] recognizes hydrological, hydromorphological, and ecological impacts as the major current threats for rivers in Europe [8].

In this vein, only a minority of students identified "biological indicators" as the best method to assess river conservation status, although the proportion of students that were aware of this was higher among university students than Primary and Secondary Education students (13\% of Primary Education students, $16 \%$ of Secondary Education students, and $30 \%$ of university students). It is well known by ecologists and managers that bioindicators are the best current tool to evaluate the health of ecosystems as a whole because they not only assess instantaneous water quality, but they integrate numerous environmental factors (both biotic and abiotic), long-term conditions, and large spatial scales [36,37]. Consequently, bioassessment tools have been broadly adopted to evaluate the ecological status of inland waters (e.g., the U.S. Clean Water Act, the Canadian Protection Act, and the European Water Framework Directive), and constant efforts are made to improve and adapt them, 
or create new ones for regions (e.g., Mexico, Peru, Ecuador) and river typologies (e.g., non-perennial streams) that lack them [38,39]. Indeed, the inclusion of biological indicators in the EU legislation as the main tool to assess river health entailed a paradigm shift in river management within Europe, recognizing the river ecosystem concept and leaving behind management that focused on water quality that reduced rivers to water channels [36]. Moreover, biological indicators are useful tools to effectively communicate the river ecosystem concept because they allow for studying biological communities inhabiting rivers, their trophic interactions, and their relationships with the abiotic components of rivers, including anthropogenic stressors. In fact, several educational resources that aim to increase awareness about river ecosystems have used biological indicators as educational tools, such as those using aquatic macroinvertebrates [13] or new technological tools specifically developed for this goal (e.g., RiuNet [40]).

\subsection{River Management}

Our results show that students were aware of some key concepts regarding the sustainable management of rivers, such as the importance of reducing water consumption to avoid water scarcity issues and the need to limit the use of agrochemicals to improve river health. However, responses to other questions showed a clear disconnection to the principles of sustainable management of both water and aquatic ecosystems. About $40 \%$ of respondents considered water transfers between watersheds a priority to improve the situation of Spanish rivers, despite the environmental problems linked to this intensive hydrological regulation [41,42]. Similarly, most students (83\% of Primary Education, $79 \%$ of Secondary Education, and $74 \%$ of university students) would eliminate plant components from rivers to clean them. These results point out the persistence of misconceptions related to water management that have already been defeated by scientific knowledge, such as the existence of watersheds with water deficit or surplus, the solidarity between watersheds, and the dirtiness of rivers generated by natural elements of the ecosystem $[43,44]$.

Regarding flood risk management, about half of the respondents perceived structural management measures as the best options to reduce flood risk. Similarly, it has been reported that people living in areas affected by river floods perceived structural management measures positively to reduce flood risk [45]. However, sustainable management should be based on adaptive land planning and, specifically, on the restoration of flood plains that have been occupied for human activities [46]. Gray infrastructures and actions such as dredging should not be perceived as plausible solutions by students, due to their low effectiveness and high environmental impact [47]. This misconception could be explained by the lack of scientific knowledge and the absence of a more holistic ecosystem concept of flood events, political interests, and inaccurate mass media communication [48]. Therefore, managers and policymakers should stop implementing structural management measures, such as dredging, breakwaters, and rockfills in riverbanks, due to their low effectiveness and high environmental impact, despite being reclaimed by citizens [47]. Ballester [49] stressed that social training on flood risk management is needed in order to reduce the number of people vulnerable to flood events. The development of social skills related to flood risk management should start in the school, where the scientific knowledge on this topic should be transferred to students.

\subsection{Differences among Educational Levels and Territories}

Despite the general misconception regarding river knowledge for all educational levels, it should be noted that the ecosystem concept of rivers increased with educational level. Students at higher educational levels showed a greater knowledge of biotic and abiotic elements that are part of river ecosystems and were able to identify less transformed rivers as better conserved ecosystems (Figure 7). Previous research has suggested that students may have difficulties understanding and internalizing several aspects related to the study of ecosystems [50], such as the knowledge and interaction among ecosystem components [51,52] or those about ecosystem dynamics [53,54]. In this vein, Marcén [31] pointed out that the ideas and attitudes towards water are complex constructions that students are 
progressively organizing, not just in the school environment. Consequently, we can expect students to be able to increase their knowledge about river ecosystems with increasing educational level and age, as we observed.

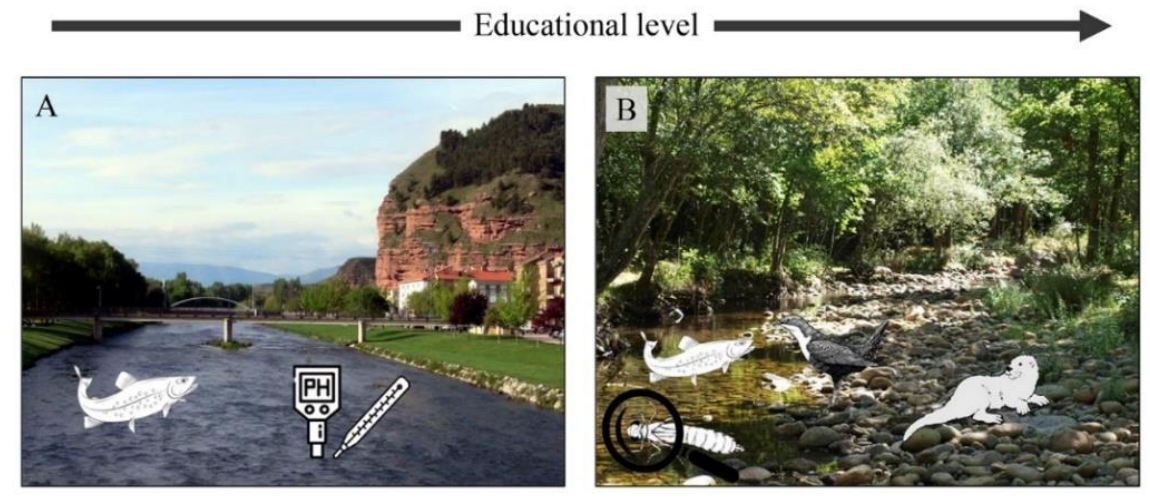

Figure 7. Images representing how the river ecosystem concept changes with educational level. (A) River ecosystem concept of Primary Education students. (B) River ecosystem concept of university students of the bachelor's degree in Primary Education. While fish were recognized as inhabitants of rivers by all educational levels, the percentage of respondents who also recognized plants, insects, and vertebrates increased with educational level. The same pattern was found for sediment and riparian forests as elements that contribute to river biodiversity. As shown, the selection of bioindicators as the best method to assess river conservation status also increased with educational level. The images also represent that non-sustainable measures (i.e., river channelization, construction of walls in river shores, and dredging and clearing vegetation growing within river channels) were less elected by university students than by students from lower educational levels.

Regarding river management, university students opted for more sustainable management models than respondents of lower educational levels, while no differences were found between Primary and Secondary Education students. That points out that training in environmentally sustainable management has not been effectively incorporated into Secondary Education, despite current legislation establishing clear curricular goals on that topic (RD 1105/2014). Poor environmental science literacy could be related to the predominance of theoretical content in textbooks and the transmission model that still characterizes this educational level, which can relegate issues related to human impact on aquatic ecosystems, or their management, to the background [31]. Even in river-related extracurricular programs developed in Secondary Education, deficits have been observed in relation to the topics discussed, especially in relation to sustainable river management [55]. Therefore, it is necessary to review the concepts and skills imparted and the methodologies used at this educational level regarding river management.

The knowledge of university students of the Bachelor of Primary Education about river ecosystems and their sustainable management is especially relevant, considering that they will play a key role in transferring that knowledge to society through student training [56,57]. Beiswenger et al. [58] showed that Wyoming's elementary educators had adequate knowledge for a few water topics, but still failed to give priority to these topics in their curricula. This brings out that educators' knowledge is essential, but other factors such as prioritization of curricular topics or pedagogical models can prevent knowledge transfer to students.

In contrast to the differences found among educational stages, no differences were found among territories. Although studies exploring geographical differences in the knowledge and attitudes towards rivers are rare, Le Lay et al. [59] found that attitudes towards the presence of large woody debris in rivers varied among geographical areas. University students living in forested landscapes perceived the presence of dead wood within river channels more positively than university students living in unforested regions, where the presence of this element is less common. Similarly, Ruiz-Villanueva et al. [11] showed that people living near the Pyrenees mountains had a more positive 
perception about the presence of dead wood within river channels than those living in the center of the Iberian Peninsula, which has been associated with the good conservation of the rivers and forests of the Pyrenees region. In this vein, Rodríguez Lozano et al. [10] found that students' perception of non-perennial streams differed between US states (Washington, California, and Arizona). More studies exploring geographical differences in the knowledge and attitudes towards rivers and the factors that shape them are needed.

\subsection{Final Remarks}

This study shows that students had a simplified vision of rivers, which generally led to a preference for non-sustainable management measures. Although this general pattern was found in all educational levels, university students of the Bachelor in Primary Education had knowledge more similar to the ecosystem concept of rivers and their sustainable management than Primary and Secondary Education students. Our large survey sample $(\mathrm{N}=3447)$ makes our results significant. To the best of our knowledge, this is the first study to explore students' knowledge about river ecosystems and their management differentiating among educational levels and territories.

While current scientific knowledge has been at least partially transferred to policymakers and incorporated into legislation (e.g., Water Framework Directive, Flood Risk Directive; [35,60]), our results show that knowledge has not been effectively incorporated in the curricula of Primary and Secondary Education. Learning standards related to ecosystems and their sustainable management are set in the educational laws, but the concepts included are still shallow and have not been updated according to current scientific knowledge and environmental legislation. Moreover, previous research [61] has highlighted that textbooks still depict rivers and their management from a hydraulic perspective and not as ecosystems. Curricula for both Primary and Secondary Education should include the concepts analyzed in this study and students should learn them from Primary Education. In this vein, proper training for future teachers, such as university students of the Bachelor in Primary Education degree, is needed so they can educate for sustainability.

Nowadays, democracies require political participation not just of stakeholders, but all of society. For instance, public participation has been recognized as a key factor to successfully implementing the EU Water Framework Directive [62,63]. It is worth noting that knowledge has been recognized as an essential precursor to meaningful discourse about policy and a key component of informed action [64]. Therefore, all citizens should have the capacity to understand and participate in evidence-based decision-making about aquatic ecosystems and all water-related politics, which is known as water-related environmental science literacy [16,23]. Achieving this goal demands that current scientific knowledge regarding river ecosystems and their sustainable management to be transferred to students during compulsory educational levels.

Author Contributions: Conceptualization, R.L., N.P. and J.R.D.; methodology, R.L., I.V., N.P. and J.R.D.; software, R.L., P.R.-L., I.V. and J.R.D.; validation, R.L. and J.R.D.; formal analysis, R.L. and J.R.D.; investigation, R.L., P.R.-L., I.V., N.P. and J.R.D.; writing-original draft preparation, R.L., P.R.-L., I.V., N.P. and J.R.D.; writing-review and editing, R.L. and P.R.-L.; project administration, R.L. All authors have read and agreed to the published version of the manuscript.

Funding: This research received no external funding.

Acknowledgments: We are grateful to Pau Fortuño, Alejandro Cano, Antonio de Pro, Valentín Gavidia, Julia Ibarra, and especially to Laura Sánchez and Fundación Nueva Cultura del Agua (FNCA) for their valuable help in this study. We thank the educational centers, especially to all the students that participated in the study. P.R.-L was supported by a Margalida Comas postdoctoral contract (PD/031/2018) funded by the Government of the Balearic Islands and the European Social Fund. We thank the Editor and the three reviewers for their help to improve this article.

Conflicts of Interest: The authors declare no conflict of interest. 


\section{References}

1. Rice, S.P.; Lancaster, J.; Kemp, P. Experimentation at the interface of fluvial geomorphology, stream ecology and hydraulic engineering and the development of an effective, interdisciplinary river science. Earth Surf. Process. Landf. 2010, 35, 64-77. [CrossRef]

2. Hynes, H.B.N. Edgardo Baldi Memorial Lecture. The stream and its valley. Verh. Int. Ver. Theor. Angew. Limnol. $1975,19,1-15$.

3. Junk, W.; Bayley, P.B.; Sparks, R.E. The flood pulse concept in river-floodplain systems. In Proceedings of the International Large River Symposium (LARS); Dodge, D.P., Ed.; Dept. of Fisheries and Oceans: Ottawa, ON, Canada, 1989; pp. 110-117.

4. Newbold, J.D.; Elwood, J.W.; O’Neill, R.V.; Winkle, W.V. Measuring nutrient spiralling in streams. Can. J. Fish. Aquat. Sci. 1981, 38, 860-863. [CrossRef]

5. Vannote, R.L.; Minshall, G.W.; Cummins, K.W.; Sedell, J.R.; Cushing, C.E. The river continuum concept. Can. J. Fish. Aquat. Sci. 1980, 37, 130-137. [CrossRef]

6. Moss, B.R. Ecology of Fresh Waters: Man and Medium, Past to Future; John Wiley \& Sons: Hoboken, NJ, USA, 2009.

7. Dresti, C.; Becciu, G.; Saidi, H.; Ciampittiello, M. The hydromorphological state in mountain rivers subject to human impacts: A case study in the north-west of Italy. Environ. Earth Sci. 2016, 75, 1-11. [CrossRef]

8. Haase, P.; Hering, D.; Jähnig, S.C.; Lorenz, A.W.; Sundermann, A. The impact of hydromorphological restoration on river ecological status: A comparison of fish, benthic invertebrates, and macrophytes. Hydrobiologia 2013, 704, 475-488. [CrossRef]

9. Ladrera, R.; Prat, N. Las políticas europeas y el consenso científico en materia de gestión y conservación de aguas no llegan a la escuela. In Proceedings of the IX Congreso Ibérico de Gestión y Planificación del Agua, Valencia, España, 7-9 September 2016; Fundación Nueva Cultura del Agua (FNCA): Valencia, España, 2016; pp. 637-648.

10. Rodríguez-Lozano, P.; Woelfle-Erskine, C.; Bogan, M.T.; Carlson, S.M. Are non-perennial rivers considered as valuable and worthy of conservation as perennial rivers? Sustainability 2020, 12, 5782. [CrossRef]

11. Ruiz-Villanueva, V.; Díez-Herrero, A.; García, J.A.; Ollero, A.; Piégay, H.; Stoffel, M. Does the public's negative perception towards wood in rivers relate to recent impact of flooding experiencing? Sci. Total Environ. 2018, 635, 294-307. [CrossRef]

12. Piégay, H.; Gregory, K.J.; Bondarev, V.; Chin, A.; Dahlstrom, N.; Elosegi, A.; Gregory, S.V.; Joshi, V.; Mutz, M.; Rinaldi, M.; et al. Public perception as a barrier to introducing wood in rivers for restoration purposes. Environ. Manag. 2005, 36, 665-674. [CrossRef]

13. Ladrera, R.; Rieradevall, M.; Prat, N. Macroinvertebrados acuáticos como indicadores biológicos: Una herramienta didáctica. Ikastorratza E-Rev. Didáctica 2013, 11, 1-18.

14. Stough, T.; Ceulemans, K.; Lambrechts, W.; Cappuyns, V. Assessing sustainability in higher education curricula: A critical reflection on validity issues. J. Clean. Prod. 2018, 172, 4456-4466. [CrossRef]

15. Giangrande, N.; White, R.M.; East, M.; Jackson, R.; Clarke, T.; Coste, M.S.; Penha-Lopes, G. A competency framework to assess and activate education for sustainable development: Addressing the un Sustainable Development Goals 4.7 challenge. Sustainability 2019, 11, 2832. [CrossRef]

16. Covitt, B.; Gunckel, K.; Anderson, C. Students' developing understanding of water in environmental systems. J. Environ. Educ. 2009, 40, 37-51. [CrossRef]

17. Tilbury, D. Environmental education for sustainability: Defining the new focus of environmental education in the 1990s. Environ. Educ. Res. 1995, 1, 195-212. [CrossRef]

18. Díez, J. El Agua: Una herramienta clave en la educación para el desarrollo sostenible. Rev. Bras. Pesqui. Educ. Ciências 2014, 14, 109-123.

19. Hicks, D.; Holden, C. Exploring the future: A missing dimension in environmental education. Environ. Educ. Res. 1995, 1, 185-193. [CrossRef]

20. Martínez-Peña, M.B.; Gil-Quílez, M.J. El río: Un tema cotidiano para el aula de ciencias. Enseñanza Cienc. 2014, 22, 257-266.

21. Díez, J. De Tales a Dalton. A vueltas con el ciclo del agua. In Proceedings of the X Congreso Ibérico de Gestión y Planificación del Agua, Coimbra, Portugal, 6-8 September 2018; Fundación Nueva Cultura del Agua (FNCA): Coimbra, Portugal, 2018; pp. 1-14. 
22. González, F.; Fernández, G. Potencialidades y limitaciones de las analogías elaboradas por estudiantes de magisterio para representar las aguas subterráneas. Ensen. Cienc. Tierra 2012, 20, 229-238.

23. Gunckel, K.L.; Covitt, B.A.; Salinas, I.; Anderson, C.W. A learning progression for water in socio-ecological systems. J. Res. Sci. Teach. 2012, 49, 843-868. [CrossRef]

24. Márquez, C.; Bach, J. Una propuesta de análisis de las representaciones de los alumnnos sobre el ciclo del agua. Ensen. Cienc. Tierra 2007, 15, 280-286.

25. Ben-zvi-Assaraf, O.; Orion, N. A study of junior high students' perceptions of the water cycle. J. Geosci. Educ. 2005, 53, 366-373. [CrossRef]

26. Dickerson, D.L.; Penick, J.E.; Dawkins, K.R.; Van Sickle, M. Groundwater in science education. J. Sci. Teacher Educ. 2007, 18, 45-61. [CrossRef]

27. Gil-Quílez, M.J.; Martínez-Peña, M.B. Construcción del modelo de río: Paso previo a la reflexión sobre gestión fluvial. In Investigación y Transferencia Para Una Educación en Ciencias: Un Reto Emocionante; De Las Heras Pérez, M.A., Lorca Marín, A.A., Vázquez Bernal, B., Wamba Aguado, A.A., Jiménez Pérez, R., Eds.; Universidad de Huelva Publicaciones: Huelva, España, 2014; pp. 269-276.

28. MECD. Real Decreto 1105/2014, de 26 de diciembre, por el que se establece el currículo básico de la Educación Secundaria Obligatoria y del Bachillerato; Ministerio de Educación Cultura y deporte: Madrid, España, 2015.

29. MECD. Real Decreto 126/2014, de 28 de Febrero, por el que se establece el currículo básico de la Educación Primaria; Ministerio de Educación Cultura y deporte: Madrid, España, 2014.

30. Heras, F. Educación para el uso sostenible del agua. Transatl. Educ. 2011, 8, 37-44.

31. Marcén, C. El agua: Argumento Educativo en la Enseñanza Obligatoria y en el Sistema Social. Ph.D. Thesis, Universidad de Zaragoza, Zaragoza, España, 2010.

32. Anderson, M.J.; Gorley, R.N.; Clarke, K.R. PRIMER + for PERMANOVA: Guide to Software and Statistical Methods; PRIMER-E. Ltd.: Plymouth, UK, 2008.

33. Clarke, K.R.; Gorley, R.N. PRIMER v6: User Manual/Tutorial; PRIMER-E Ltd., Plymouth Marine Laboratory: Plymouth, UK, 2006.

34. Díez, J.R.; Sarriegi, M.; Elosegi, A. La madera muerta y la ecología fluvial: Ecología y gestión. In Procesos Hidrosedimentarios en Sistemas Fluviales; Batalla, R., Tena, A., Eds.; Milenio: Lleida, España, 2016; pp. 245-275.

35. European Commission. Water Framework Directive 2000/60/EC of the European Parliament of the Council of 23 October 2000 Establishing a Framework for Assemblage Action in the Field of Water Policy; European Commission: Brussels, Belgium, 2000.

36. Bonada, N.; Prat, N.; Resh, V.H.; Statzner, B. Developments in aquatic insect biomonitoring: A comparative analysis of recent approaches. Annu. Rev. Entomol. 2006, 51, 495-523. [CrossRef]

37. Prat, N.; Munné, A. Biomonitoreo de la calidad del agua en los ríos ibéricos: Lecciones aprendidas. Limnetica 2014, 33, 47-64.

38. Castro-López, D.; Rodríguez-Lozano, P.; Arias-Real, R.; Guerra-Cobián, V.; Prat, N. The influence of riparian corridor land use on the pesquería river's macroinvertebrate community (N.E. Mexico). Water 2019, 11, 1930. [CrossRef]

39. Soria, M.; Gutiérrez-Cánovas, C.; Bonada, N.; Acosta, R.; Rodríguez-Lozano, P.; Fortuño, P.; Burgazzi, G.; Vinyoles, D.; Gallart, F.; Latron, J.; et al. Natural disturbances can produce misleading bioassessment results: Identifying metrics to detect anthropogenic impacts in intermittent rivers. J. Appl. Ecol. 2020, 57, 283-295. [CrossRef]

40. Prat, N.; Rieradevall, M.; Fortuno, P.; Ladrera, R.; Verkaik, I.; Becerra, M.; Menendez, S. Riu.Net Application: Citizen science in rivers. In Proceedings of the COWM2016-International Conference on Citizen Observatories for Water Management, Venice, Italy, 7 June 2016; pp. 7-9.

41. Poff, N.L.; Zimmerman, J.K.H. Ecological responses to altered flow regimes: A literature review to inform the science and management of environmental flows. Freshw. Biol. 2010, 55, 194-205. [CrossRef]

42. Ladrera, R.; Prat, N. Changes in macroinvertebrate community and biotic indices associated with stream flow regulation and wastewater inputs in sierra cebollera natural park (La Rioja, Northern Spain). Limnetica 2013, 32, 353-372.

43. Masip, I. Aproximación a la problemática de la pervivencia de los hidromitos como principal obstáculo para avanzar hacia una nueva cultura del agua. Arx. Cienc. Soc. 2013, 29, 115-128.

44. Peñas, V.; Masip, I. Destejiendo Tópicos del Agua; Solidaridad Internacional/Fundación Tomás y Valiente: Bilbao, España, 2011. 
45. Peño, G. Percepción del Ebro y Sus Crecidas en Zaragoza y en Municipios Ribereños. Master's Thesis, Universidad de Zaragoza, Zaragoza, España, 2018.

46. Ollero, A. Territorio Fluvial: Diagnóstico y Propuesta Para la Gestión Ambiental y de Riesgos en el Ebro y los Cursos Fluviales de Sus Afluentes; Fundación Nueva Cultura del Agua: Zaragoza, España, 2007.

47. Ollero, A.; Ibisate, A.; Elso, J. El territorio fluvial y sus dificultades de aplicación. Geographicalia 2009, 56, 37-62. [CrossRef]

48. Marcen, C.; Ollero, A. Conocimiento geográfico aplicado a la cultura social del agua: Las inundaciones. In Análisis Espacial y Representación Geográfica: Innovación y Aplicación; De la Riva, J., Ibarra, P., Montorio, R., Rodrigues, M., Eds.; Universidad de Zaragoza/Asociación de Geógrafos Españoles: Zaragoza, España, 2015; pp. 245-254.

49. Ballester, A. Participación Pública Para Una Gestión Eficaz Del Riesgo Por Inundación: Construcción De Capacidades Sociales En La Ribera Alta Del Ebro (España). Ph.D. Thesis, Universidad Autónoma de Barcelona, Barcelona, España, 2017.

50. Sánchez, F.J.; Pontes, A. La comprensión de conceptos de ecología y sus implicaciones para la educación ambiental. Rev. Eureka Sobre Ensen. Divulg. Cienc. 2010, 7, 270-285.

51. García, J.E. El conocimiento escolar como un proceso evolutivo: Aplicación al conocimiento de nociones ecológicas. Investig. Esc. 1994, 23, 65-76.

52. Rojero, F. Entender la organización. Aspectos didácticos del estudio de los ecosistemas. Alambique 1999, 20,55-64.

53. Hogan, K. Assessing students' systems reasoning in ecology. J. Biol. Educ. 2000, 35, 22-28. [CrossRef]

54. Ibarra Murillo, J.; Gil Quílez, M.J. Uso del concepto de sucesión ecológica por alumnos de secundaria: La predicción de los cambios en los ecosistemas. Ensen. Cienc. 2009, 27, 19-32.

55. Conde, O. Foro Joven: Ríos para vivirlos. Una experiencia de reflexión en torno a los ríos en la cuenca del Ebro. In Agua y Sostenibilidad: Recursos, Riesgos y Remedios; Ministerio de Educación Cultura y Deporte: Madrid, España, 2009; pp. 265-282.

56. De Lange, D. How do universities make progress? Stakeholder-related mechanisms affecting adoption of sustainability in university curricula. J. Bus. Ethics 2013, 118, 103-116. [CrossRef]

57. Disterheft, A.; Caeiro, S.; Azeiteiro, U.M.; Leal-Filho, W. Sustainability science and education for sustainable development in universities: A way for transition. In Sustainability Assessment Tools in Higher Education Institutions; Springer: Cham, Switzerland, 2013; pp. 3-27.

58. Beiswenger, R.; Sturges, E.L.; Jones, R. Water education in Wyoming: Assessing educators' knowledge of water topics and their use in the elementary curriculum. J. Environ. Educ. 1991, 23, 24-26. [CrossRef]

59. Le Lay, Y.-F.; Piégay, H.; Gregory, K.; Chin, A.; Dolédec, S.; Elosegi, A.; Mutz, M.; Wyzga, B.; Zawiejska, J. Variations in cross-cultural perception of riverscapes in relation to in-channel wood. Trans. Inst. Br. Geogr. 2008, 33, 268-287. [CrossRef]

60. European Commission. Directive 2007/60/EC of the European Parliament and of the Council of 23 October 2007 on the Assessment and Management of Flood Risks; European Commission: Brussels, Belgium, 2007.

61. Cuello, A.; García, F. ¿Ayudan los libros de texto a comprender la realidad fluvial de la ciudad? Rev. Humanid. 2019, 37, 209-234.

62. Mouratiadou, I.; Moran, D. Mapping public participation in the water framework directive: A case study of the pinios river basin, greece. Ecol. Econ. 2007, 62, 66-76. [CrossRef]

63. Jager, N.W.; Challies, E.; Kochskämper, E.; Newig, J.; Benson, D.; Blackstock, K.; Collins, K.; Ernst, A.; Evers, M.; Feichtinger, J.; et al. Transforming european water governance? Participation and river basin management under the EU Water Framework Directive in 13 member states. Water 2016, 8. [CrossRef]

64. Robelia, B.; Murphy, T. What do people know about key environmental issues? A review of environmental knowledge surveys. Environ. Educ. Res. 2012, 18, 299-321. [CrossRef]

Publisher's Note: MDPI stays neutral with regard to jurisdictional claims in published maps and institutional affiliations. 